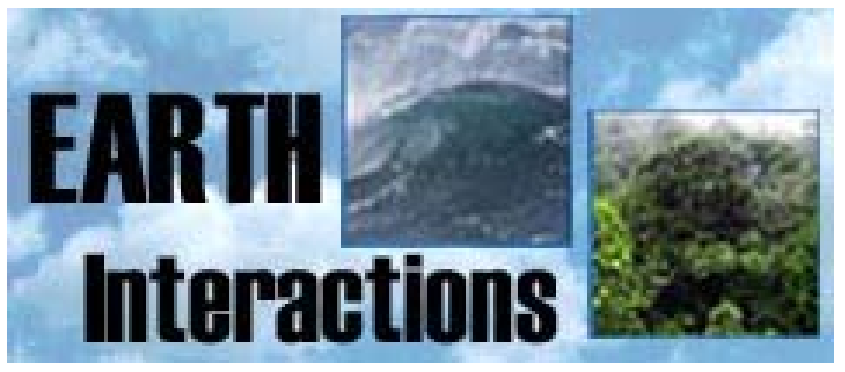

Copyright (C) 2004, Paper 8-018; 7,663 words, 8 Figures, 0 Animations, 5 Tables. http://EarthInteractions.org

\title{
The Relationship of the Terra MODIS Fire Product and Anthropogenic Features in the Central Siberian Landscape
}

\section{Katalin Kovacs*}

Science Systems and Applications, Inc., Seabrook, Maryland

\section{K. Jon Ranson}

NASA Goddard Space Flight Center, Greenbelt, Maryland

\section{Guoqing Sun}

University of Maryland, College Park, College Park, Maryland

\section{Vlacheslav I. Kharuk}

Sukachev Institute of Forest, Krasnoyarsk, Russia

Received 9 April 2004; accepted 3 June 2004

ABSTRACT: Fires are a common occurrence in the Siberian boreal forest. The thermal anomalies product of the Terra/Moderate Resolution Imaging Spectroradiometer (MODIS) product suite is designed to detect thermal anomalies (i.e., hotspots or fires) on the Earth's surface. Many, but not all, of

*Corresponding author address: Katalin Kovacs, Science Systems and Applications, Inc., Seabrook, MD 20706

E-mail address: kkovacs@ltpmail.gsfc.nasa.gov 
the hot spots detected by MODIS in Siberia are wild fires. Agricultural burning and industrial activities also contribute. Using MODIS data from the years 2001, 2002, and 2003 along with a geographical information system (GIS), the type, extent, and duration of hot spots were examined. In addition, high correlations were found between the number of fires and proximity to human activities. Different types of land-cover thermal anomalies were found to have a strong, positive correlation with some anthropogenic features, such as roads, human settlements, and mineral industry locations. The agricultural $\left(r^{2}=0.95\right)$ and the forest $\left(r^{2}=0.81\right)$ thermal anomalies had the highest positive correlation with proximity to roads. The correlation was stronger between burned forests and roads $\left(r_{2001}^{2}=0.81, r_{2002}^{2}=0.90, r_{2003}^{2}=0.88\right)$ than between any forested land and roads $\left(r^{2}=0.52\right)$. The results indicate that forest fires tend to occur near agricultural fires $\left(r^{2}{ }_{2001}=0.93, r^{2}{ }_{2002}=0.87, r_{2003}^{2}=0.94\right)$. Anthropogenic feature and land-cover thermal anomaly (LCTA) relationships tend to be stronger in a high fire year (2003) than in a low fire year (2001). This alone does imply causation, but might be an indicator of natural and anthropogenic factors acting together to shape where and when fires are burning. These findings have important implications for carbon and climate modelers wishing to use MODIS products to quantify and predict carbon storage and climate change.

KEYWORDS: Boreal; Fire; Humans

\section{Introduction}

The vast expanse of boreal forest in Siberia is continually changing through various disturbance mechanisms such as insect defoliation, logging, mineral exploitation, and especially fires. Patterns of disturbance and forest recovery processes are important factors regulating ecosystem dynamics and carbon flux in this area. Earth-observing satellites that provide timely, wide area coverage of fires have been used for fire-monitoring work in Siberia. To estimate fire extent, carbon consumption, and emissions for the severe fire year of 1998, Kasischke and Bruhwiler (Kasischke and Bruhwiler 2002) used the Advanced Very High Resolution Radiometer (AVHRR) in North America, the Russian Far East, and Siberia. The results indicated that there is an order of magnitude interannual variation in emissions associated with burning from low to high fire years in the boreal forest. A similar study was conducted by Kajii et al. (Kajii et al. 2002) in which the authors used AVHRR data to estimate the amount of burned area and emissions from the boreal forest during the severe fire year of 1998. The total area burned was estimated to be $1.1 \times 10^{7}$ ha.

To constrain estimates of biomass-burning emissions for six regions, including Asiatic Russia, Duncan et al. (Duncan et al. 2003) used AVHRR, Total Ozone Mapping Spectrometer (TOMS), and Along Track Scanning Radiometer (ATSR) observations. The data showed no emissions trend during the last two decades; however, the existence of significant interannual variability was confirmed. The authors related the largest $\mathrm{CO}$ releases to forest wildfires resulting from ENSOinduced droughts. In Scandinavia, Kelha et al. (Kelha et al. 2003) used ATSR and AVHRR to develop an operational system for boreal forest fire detection. The 
authors concluded that fire detection was improved by using data from two satellite systems. The National Aeronautics and Space Administration's (NASA's) Terra MODIS instrument has been employed for global fire mapping since the year 2000 (Justice et al. 2002; Giglio et al. 2003) and is being used extensively for routine fire-monitoring operations around the globe. Although there are a number of studies investigating the relationship of social factors and fire regimes in South and North America, none was found addressing these issues in Siberia. In a study using satellite and ground-based data to analyze the environmental and social factors influencing fires in the Upper Midwestern part of the United States, Cardille et al. (Cardille et al. 2001) found that the spatial distribution of fires is related to biotic, abiotic, and human factors at two different spatial scales. The authors found that the humans have a significant influence on modern fire regimes in the Upper Midwest, and this influence should be explicitly considered in future fire assessments. Cochrane and Laurance (Cochrane and Laurance 2002) analyzed the relationship of fires and forest fragments in the Amazonian forests. The results showed that fire rotation time was lower near the edge of the forest fragment than in nonfragmented forest stands, indicating that human-caused forest fragmentation increased the likelihood of fires. The authors argue that this is because forest edges are drier than forest stands and they are adjacent to frequently burned pastures. Rodriguez-Trejo and Fule (Rodriguez-Trejo and Fule 2003) studied the fire ecology of Mexican pines and concluded that long-term historical fire regime patterns have been altered by a combination of natural and anthropogenic fires and that pine forests are endangered by excessive anthropogenic fire, which eventually leads to deforestation. In their paper on the dynamics of an anthropogenic fire regime in Missouri, Guyette et al. (Guyette et al. 2002) examined dendrochronological fire histories coupled with human population data. The authors found that the relationship of percent sites burned and human population density was a complex one. When population density was less than 0.64 humans per squared kilometer, the percentage of sites burned was logarithmically related to human population $\left(r^{2}=0.067\right)$. When population density was between 0.64 and 3.4 humans per squared kilometer, the percentage of sites burned was independent of population increases. When population density rose above 3.4 humans per squared kilometer, the percent of sites burned was inversely related to population $\left(r^{2}=\right.$ 0.018 ).

Of interest to carbon cycle modelers is the distinction between natural and anthropogenic disturbance factors (e.g., Kobak et al. 1996). In west-central Canada, Li et al. ( $\mathrm{Li}$ et al. 2003) estimated the temporal changes of forest net primary production associated with natural and anthropogenic disturbances from 1920 to 1995 . However, in this study, insect disturbance and all wildfires were assumed "natural" disturbance mechanisms and only forest harvest was assumed anthropogenic. The authors found that natural disturbances (such as insect damage and fires) played a greater role than harvest in determining the temporal net primary productivity (NPP) patterns because more area was affected by natural disturbance. A reliable way to distinguish between natural and anthropogenic origins of fires would be to refine NPP and net ecosystem productivity (NEP) estimates globally. Natural and human-induced ecosystem change is also of interest to natural and social scientists working on incorporating complex fire-human 
interaction into a modeling framework. In their 2003 paper, Chapin et al. modeled change in human-fire interaction in the Alaskan boreal forest. Chapin et al. (Chapin et al. 2003) point out that studies are needed on the way in which fire policy, settlement policy, and cultural and socioeconomic variables affect future fire regimes.

What is meant by influence of human activities must be discussed especially in light of potentially incomplete input data layers. Areas around transportation lines and settlements are influenced by people because people use transportation for both business and recreation. People who drive along roads might stop and hike into the woods, make a fire, or smoke. We assume a person can walk up to $20 \mathrm{~km} \mathrm{day}^{-1}$ from a point without needing to carry major supplies, such as food and water. In rural areas, trash is burned on a regular basis and pastures and agricultural fields are also burned regularly in the spring and sometime also in the fall to clear fields and recycle nutrients. Sparks may be carried by wind for kilometers, and if conditions are right (warm, dry, and potential fuel is present), might ignite the surrounding natural vegetation.

It also must be pointed out that both people and fires favor warm and dry conditions. In the northern areas of Siberia (above $65^{\circ} \mathrm{N}$ ) winters are severely cold, summers are cool and short, the soil is frozen for most of the year, and when the top of the soil column thaws, the tundra turns soggy. The forest cover is sparse because of the harsh climate. For these reasons, the human population density is very low. For these very same reasons, fires are also rare. In the southern part of Siberia (below $65^{\circ} \mathrm{N}$ ), however, summers are longer, warmer, and drier. The population density is higher because this area is more favorable for agriculture and hunting. For these climatic reasons, fires are naturally more likely. Therefore, the presence of people and fires in the southern parts of Siberia are at least somewhat independent. There would be more fires in the southern part of Siberia than in the north even if people were not present.

A first step in the process of understanding the relationship of fires and human activity is to gain understanding of the location, extent, and duration of fires with respect to land cover and cultural features. The objective of this research was to use MODIS data and georeferenced spatial information to investigate the relationship between thermal anomalies, land-cover types, and human activities. In addition, using these information sources, the frequency, extent, persistence, and land-cover type of fires occurring away from known human activities were evaluated.

\section{Study area and data}

\section{1. Study area description}

The area of this study is located in central Siberia, covering parts of West Siberian Basin and the central Siberian Plateau, ranging from $50^{\circ}$ to $75^{\circ} \mathrm{N}$ in latitude and from $80^{\circ}$ to $100^{\circ} \mathrm{E}$ in longitude and covering more than 5.8 million $\mathrm{km}^{2}$ (Figure 1). Along the Yenisey River, forests with pine (Pinus sylvestris), larch (Larix sibirica, L. gmelinii), Siberian pine (Pinus sibirica), spruces (Picea obovata), and fir (Abies sibiricus) cover most of the landscape. Deciduous stands with birch (Betula pendula, B. pubescens) and aspen (Populus tremula) cover the areas of lower 


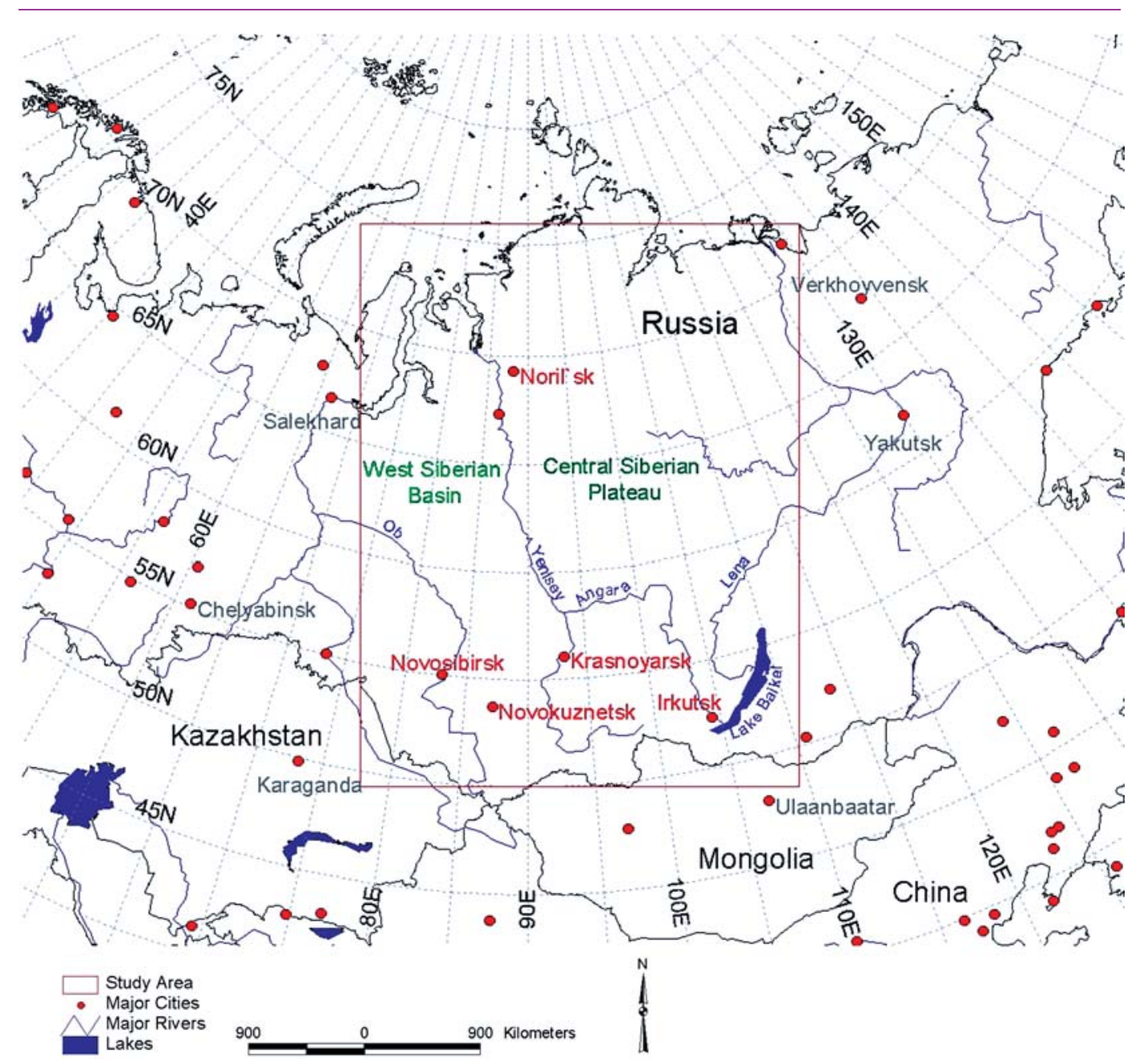

Figure 1. Map of central Siberia with the study area outlined in red.

elevation (under $500 \mathrm{~m}$ ) in this region. The climate of this area is distinctly continental with long, cold winters and short, hot summers. The main regional population centers include Novosibirsk (population: 1.4 million), Krasnoyarsk (911 700), Irkutsk (593 400), Novokuzneck (501 000), Tomsk (487 700), and Norilsk (135 100), where the population numbers are projections for 2002 based on official census data (Brinkhoff 2003).

This area of Siberia is economically important for oil and gas resources, forest resources, nickel, copper, gold and platinum deposits, mines, and processing plants. In addition, there are significant agricultural areas in the southeastern portion of the study area.

\subsection{MOD 14 thermal anomaly data}

Terra MODIS Thermal Anomalies version 4 (MOD14) 8-day composites at 1-km resolution data, acquired from 6 March to 1 November for years 2001, 2002, and 
2003, were ordered and obtained from the Eros Data Center (EDC) Distributed Active Archive Center (DAAC). The MOD14 fire-detection strategy is based on absolute detection of strong fires and on detection relative to the background to account for variability of the surface temperature and reflection of sunlight (Justice et al. 2002). For absolute fire detection, the algorithm requires that at least one of the following conditions be satisfied: 1$) \mathrm{T} 4>360 \mathrm{~K}$ (330 K at night) or 2) T4 > $320 \mathrm{~K}(315 \mathrm{~K}$ at night) and $\mathrm{T} 4-\mathrm{T} 11>20 \mathrm{~K}(10 \mathrm{~K}$ at night), where $\mathrm{T} 4$ and $\mathrm{T} 11$ are MODIS channel 22 and 31 temperatures, respectively (Justice et al. 2002). In this study, only those pixels were used that were flagged as "nominal or high confidence fire" by the MODIS fire product team.

The data were mosaicked, subsetted, and projected to the Lambert conformal conic projection using the MODIS reprojection tool version 3.1 (USGS 2003). The thermal anomalies (TAs) data were ingested into a raster database in the Environment of Visualizing Images (ENVI) v3.4 image-processing software (RSI 2000) so the location, burn date, and area of the TAs were easily accessible. Figure 2a shows the locations of all thermal anomalies in the study area for 2001, Figure $2 \mathrm{~b}$ shows the same data for 2002, and Figure 2c shows these data for 2003.

\subsection{Ancillary data}

Vector data representing natural and anthropogenic features were obtained from a wide range of sources. Major roads, railroads, rivers, and populated areas for the Krasnoyarsk district were obtained from the Sukachev Institute of Forest, which is based in Krasnoyarsk. The Krasnoyarsk district covers about a quarter of the entire study area.

Additional coverage for major roads and railroads were digitized from a publicly available transportation map at a 1:38 000000 scale (CIA 1994). We acknowledge that this dataset only includes major roads for this region, but since local and dirt roads are connected to major roads, the major roads are representative of the road network as a whole. Oil and gas pipeline data were obtained from the same source at the same scale (CIA 1994). Data on mineral resources and mineral industry locations at a 1:1 000000 scale (Mason and Arndt 1996; Causey and Douglas 1998) in Siberia were downloaded from the United States Geological Survey (USGS) Energy Resources Program Web site (http://energy.usgs.gov). The oil and gas resources dataset at a 1:15 700000 scale was obtained from the Energy Information Administration (Energy Information Administration 1997). This dataset includes abandoned, developing, and active oil and gas resources. For the purposes of this study, only the active resources were used. The data were subsetted, reprojected, and ingested into the database.

\subsection{Derived vector data}

The Defense Meteorological Satellite Program (DMSP) Operational Linescan System (OLS) has a unique low-light imaging capability developed for the detection of clouds using moonlight. In addition to moonlit clouds, the OLS also detects lights from anthropogenic light sources. This dataset is known as the Stable Lights of the World (Elvidge et al. 2001). By analyzing the location, frequency, and appearance of lights observed in an image times series, the National Oceanic 
Earth Interactions - Volume 8 (2004) • Paper No. 18 • Page 7

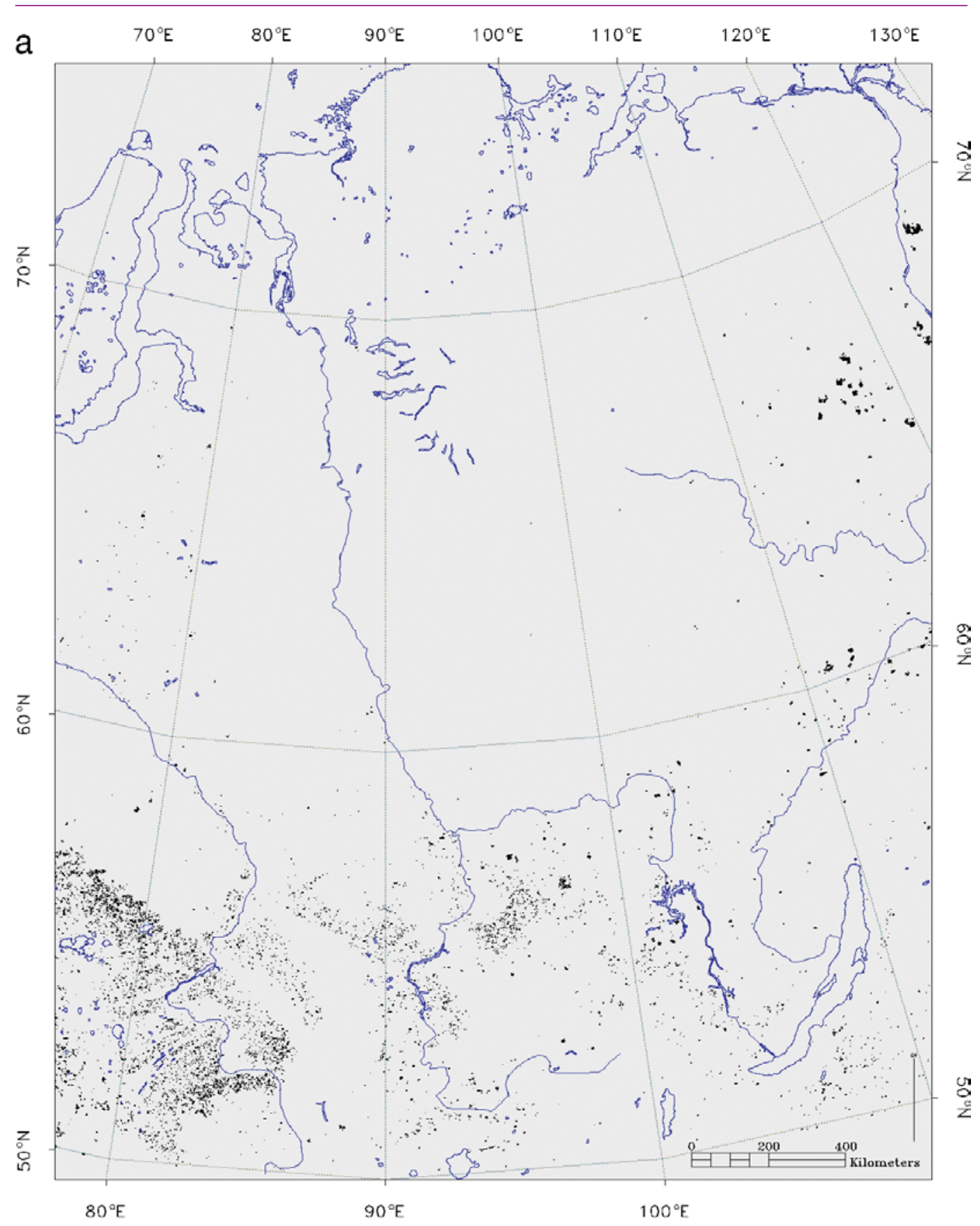

Figure 2. (a) Locations of all MODIS-detected thermal anomalies in the study area that occurred between 1 Mar and 1 Nov 2001 are shown as black polygons. Water features are shown in blue. The small black rectangle is the area shown in Figure 3. (b) Locations of all MODIS-detected thermal anomalies in the study area that occurred between 1 Mar and 1 Nov 2002 and (c) 1 Mar and 1 Nov 2003 are shown as black polygons. Water features are shown in blue. 
Earth Interactions - Volume 8 (2004) - Paper No. 18 • Page 8

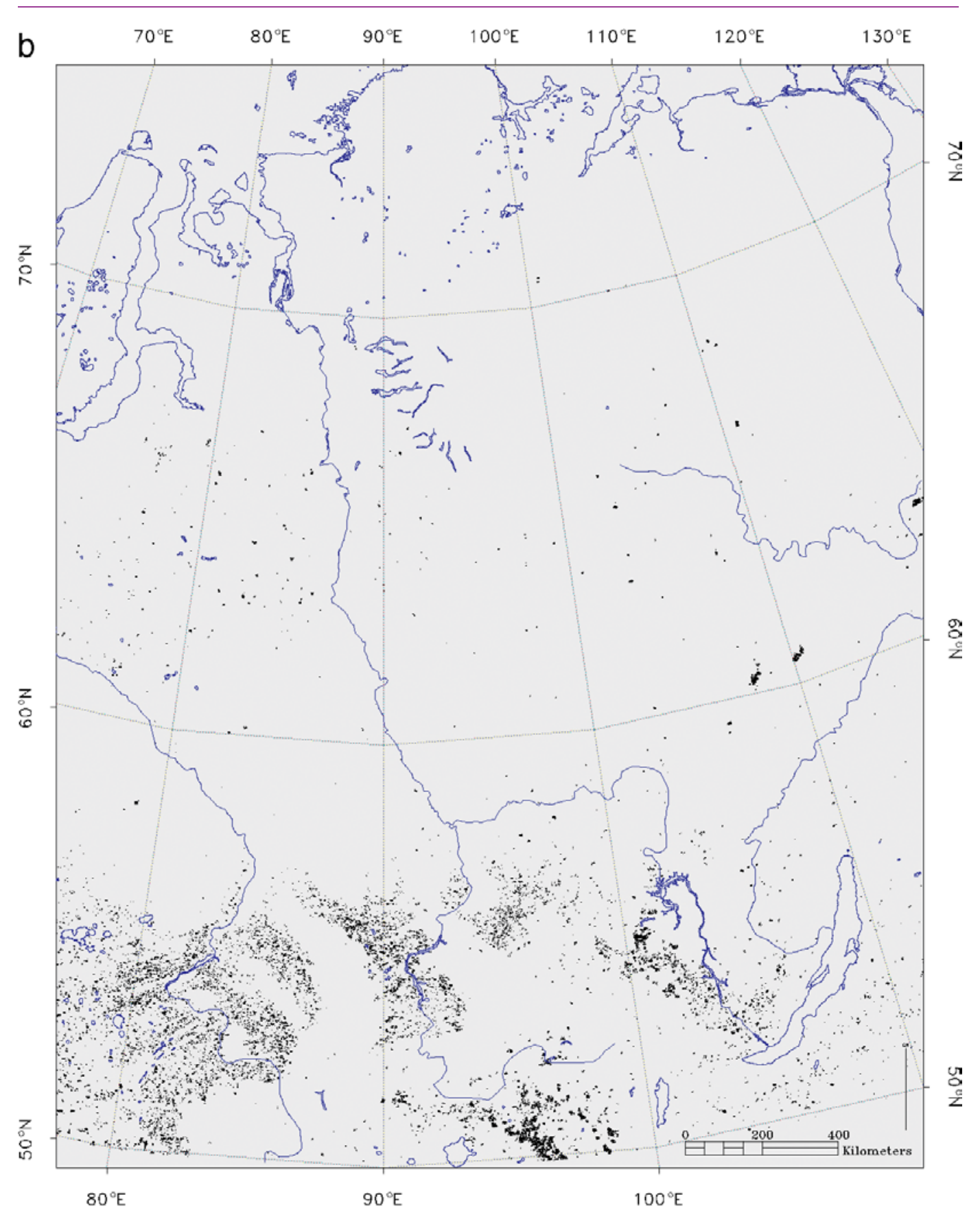

Figure 2. (continued)

and Atmospheric Administration-National Geophysical Data Center (NOAANGDC) Solar-Terrestrial Physics Division generated datasets representing the four primary types of lights present at the Earth's surface: human settlements, fires, gas flares, and fishing boats, as observed during a 6-month period in 1994-95 
Earth Interactions - Volume 8 (2004) • Paper No. 18 • Page 9

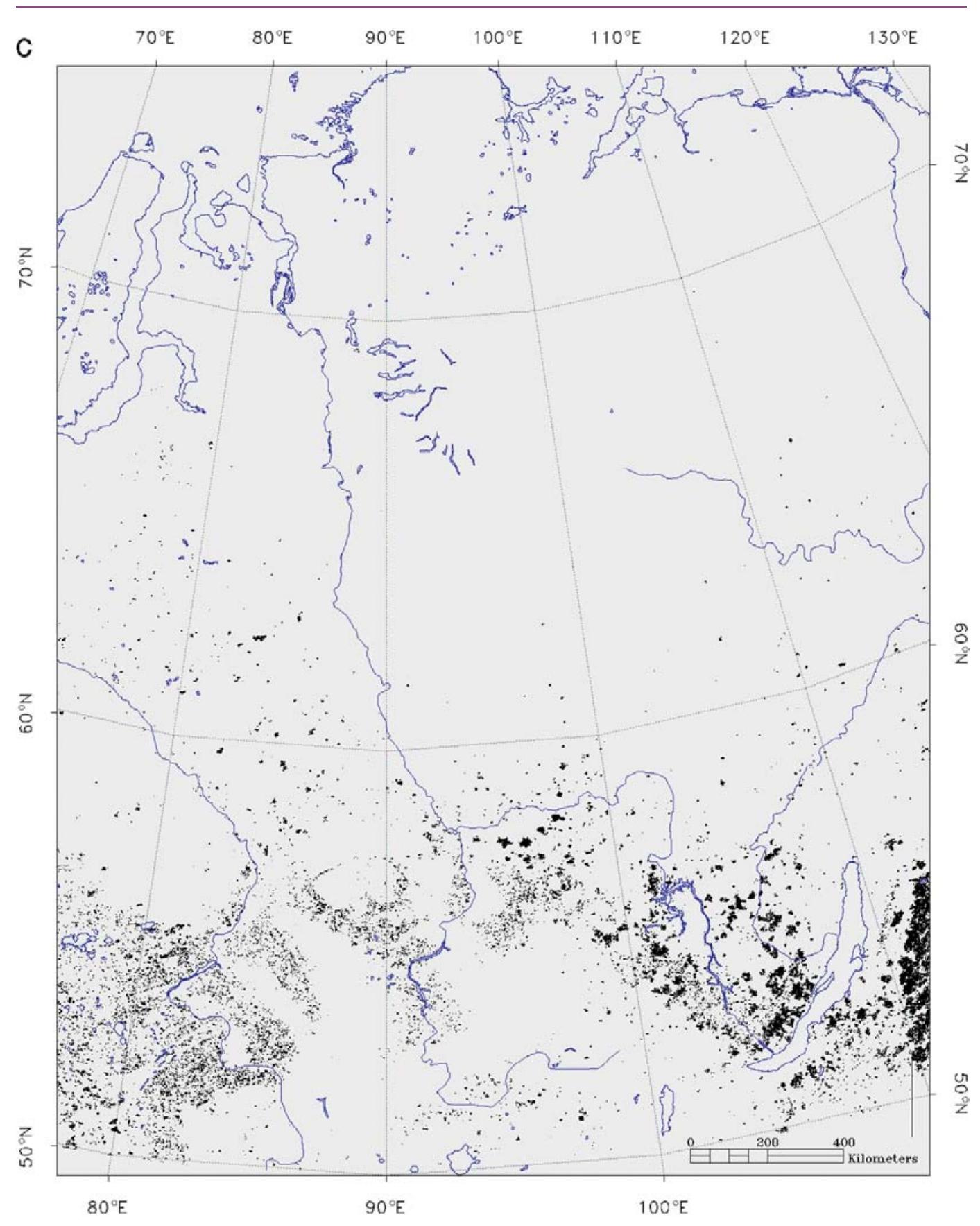

Figure 2. (continued)

(NOAA-NGDC 2001). These human settlements and gas flares data were obtained, subsetted, reprojected, and converted to vector data. These additional human settlements data were merged with the Sukachev Institute's data on populated areas, taking care that there were no duplicate data points for any 
settlement. Once the MOD14 thermal anomalies dataset, the gas flares data, and the active oil and gas resources dataset were overlaid, it was apparent that a thermal anomaly occurred very near a number of gas flares and active oil and/or gas resource centers. A subset of this natural gas and oil basin is shown in Figure 3. This indicates that not all MOD14 thermal anomalies are burning land cover. A method was developed to distinguish between land-cover thermal anomalies (LCTAs) and industrial thermal anomalies (ITAs) as discussed in the following section.

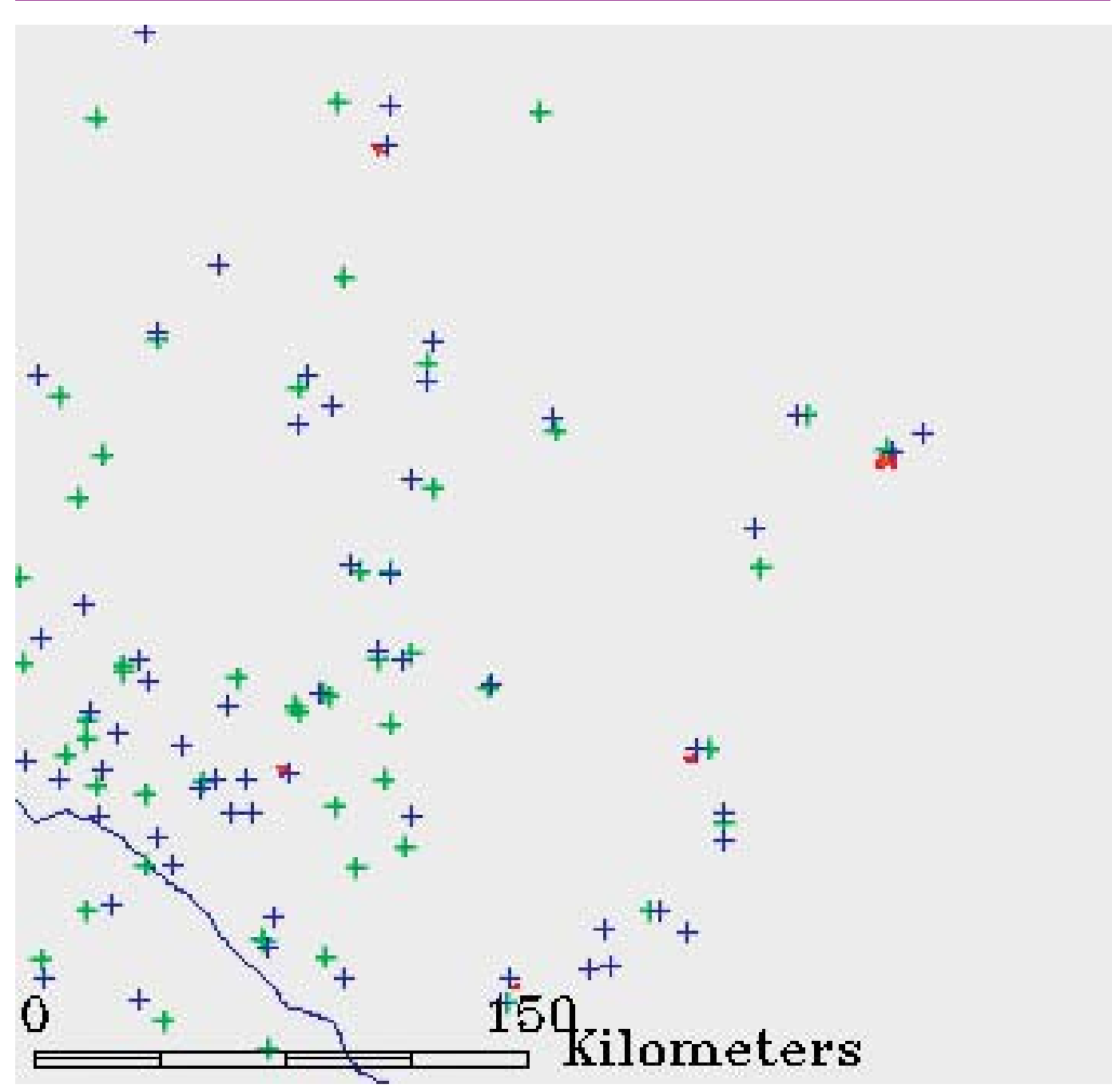

Figure 3. MOD 14 thermal anomalies for 2001 are shown in red. The centers of gas flares in 1994-95 are shown with blue crosses, and the oil and gas resources (which were active in 1997) are shown with green crosses. Oil or gas extraction facilities such as 1) Verkhne-Kolikyeganskoye and 2) Khokhryakovskoya, which has been active since 1994, are shown with all three colors. Others shown in green or blue are either no longer active or the heat they emit are too small for detection. The small black rectangle is the area shown in Figure 4. 


\section{Methods}

\subsection{Land-cover mapping}

A current land-cover map of the study area was required to identify the type of TAaffected land cover. A number of land-cover maps are available for our area including the MODIS MOD12 (Friedl et al. 2002) International GeosphereBiosphere Program (IGBP) product for 2001, the MOD12 University of Maryland product for 2001, the Systeme pour l'Observation de la Terre (SPOT) vegetationbased map of global land cover (GLC) 2000 (Bartelev et al. 2003), and an AVHRR-derived product of central Siberia (Kharuk et al. 2003). We used these maps to help develop a 500-m land-cover classification from 2001 MODIS MOD13 Normalized Difference Vegetation Index (NDVI) and middle infrared (MIR) products for seven 16-day periods. The training and test data were derived from areas of agreement between intensively mapped sites (Ranson et al. 2003) and the above land-cover products. At least 10 polygons of about 300 pixels each were used to train each class, and at least $30 \%$ of these were set aside for testing the maximum likelihood classification.

\subsection{Distinguishing ITAs and LCTAs}

To separate the LCTAs from those associated with industrial activities-that is, ITAs - the persistence of thermal anomalies was examined. Since MODIS products use an 8-day compositing method, the persistence classes were defined as follows: pixels with thermal anomalies that persisted for 8 or less days were labeled as class 1 , pixels with thermal anomalies that persisted for longer than 8 days but less than 16 days were labeled as class 2, pixels with thermal anomalies that persisted for longer than 16 days but less than 24 days were labeled as class 3 , and so on. Table 1 shows these results. Over $96 \%$ of all thermal anomalies were found to be class 1 . A very small amount $(0.2 \%)$ of thermal anomalies lasted longer than 40 days (class 5). These classes of thermal anomalies were overlaid with the gas flares, oil and gas resources, and mineral industrial locations. Only class 3, 4, and 5 anomalies coincided with the presence of a known industrial heat source (such as gas flares, oil refineries, and smelters). A small percentage of the class 1 and class 2 anomalies occurred on the edges of class 3 or higher thermal anomalies, and a small percentage of class 3 anomalies occurred in areas with no known industrial activity. Therefore, we concluded that thermal anomalies that persisted more than 16 days (class 3 and above) were ITAs, and the class 1 and 2 thermal anomalies (those that lasted for 16 days or less) were LCTAs. The small amount of

Table 1. Continuous thermal anomaly persistence classes.

\begin{tabular}{ccrrr}
\hline 8 -day periods & Continuous TA & Pixels & Percent & Area $\left(\mathrm{km}^{2}\right)$ \\
\hline 1 & 0 day $<\mathrm{TA} \leq 8$ day & 30424 & $97 \%$ & 26123 \\
2 & 8 day $<\mathrm{TA} \leq 16$ day & 819 & $3 \%$ & 703 \\
3 & 16 day $<\mathrm{TA} \leq 24$ day & 59 & $<1 \%$ & 51 \\
4 & 24 day $<\mathrm{TA} \leq 32$ day & 23 & $<1 \%$ & 20 \\
$5+$ & 32 day $<\mathrm{TA}$ & 68 & $<1 \%$ & 58 \\
Total & & 31393 & $100.00 \%$ & 26955 \\
\hline
\end{tabular}


confusion between ITAs and the LCTAs indicates the accuracy was sufficient for our purposes. Only about $0.48 \%$ of all thermal anomalies had an industrial origin. The rest were land-cover thermal anomalies.

When the industrial areas and the ITAs were inspected on Terra Advanced Spaceborne Thermal Emission and Reflection Radiometer (ASTER) images, in some cases there was no forest or other land adjacent (contiguous) to the ITA pixels. In other cases an extensive area around the source of the ITA was flagged as a thermal anomaly, but the ASTER images revealed no evidence of land-cover burning. For example, Figure 4 shows an industrial facility on ASTER visible nearinfrared (VNIR), shortwave infrared (SWIR), and thermal infrared (TIR) images. The area flagged as a thermal anomaly on the MOD14 (acquired from 6 March 2001 to 1 November 2001) data is shown as the shaded polygon. The bright region on SWIR and TIR images shows a gas flare. Since the ASTER images revealed no land-cover burning near the ITAs, the LCTA pixels on the edges of ITAs were an error. Therefore, to eliminate those misclassified LCTAs from the edges of industrial heat islands, we located all LCTAs that were contiguous with the ITAs, and we assigned them to the industrial thermal anomaly class. This operation only affected about 200 pixels and refined the spatial definition of ITAs. These erroneous LCTA pixels might have occurred because of changes in wind direction. If the wind temporarily changed the direction of the gas flare, an adjacent MODIS pixel might have been flagged as a thermal anomaly for a brief period of time.

\subsection{Spatial feature analysis}

Vector data including roads, railroads, rivers, human settlements, oil and gas resources, gas flares, mineral resources, and mineral industry locations data were projected to the Lambert conformal conic projection using the ARC8.1 (ESRI 2001) software, and they were ingested into ENVI 3.4 software along with the MODIS data. A continuous, unlimited buffer zone was created around each feature on the base thermal anomaly map. This buffer zone was incremented by one pixel, which equals approximately $1 \mathrm{~km}$. The unlimited buffer zone means that there was no upper distance limit set above which all values would be the same. Continuous buffer means that the distance between each pixel in the study area and the closest vector feature is assigned to each pixel in the output buffer image. In this way, a continuous field of distance from each vector feature was created. The buffer image of the human settlements can be seen in Figure 5. Similar continuous, unlimited buffer zones were created around each type of LCTAs and the ITAs.

A correlation matrix was generated from the above 10 buffer zone images by correlating the distance values in each pair of images. The correlation measure is the ratio of the covariance of both variables squared, divided by the product of the variance of each variable (Clark and Hosking 1986). Even though the main goal of this study is to detect whether or not land-cover fires are more likely to occur in areas that are actively being modified by people, computing the correlation between various anthropogenic features (such as roads and human settlements) was also of interest.

High positive correlation values mean that the distance in space from any image pixel to a feature $\mathrm{X}$ (e.g., railroads) is similar to the distance from any image pixel 
Earth Interactions • Volume 8 (2004) • Paper No. 18 • Page 13

a
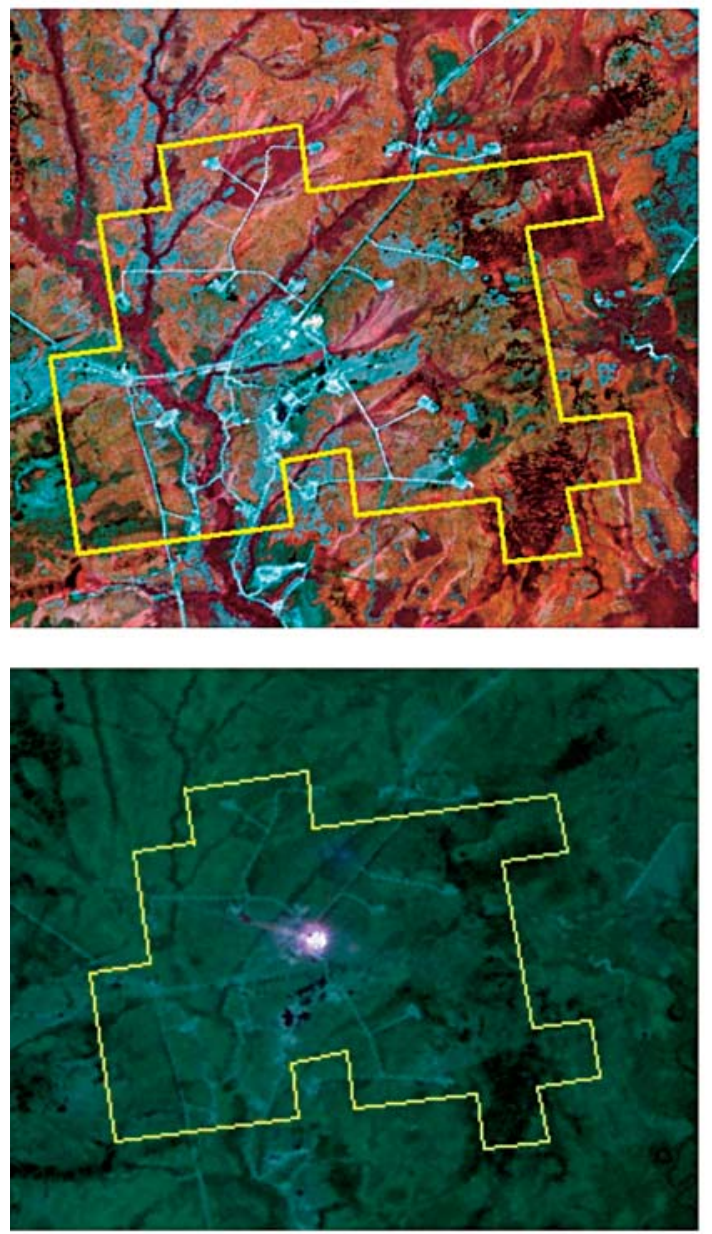

c b
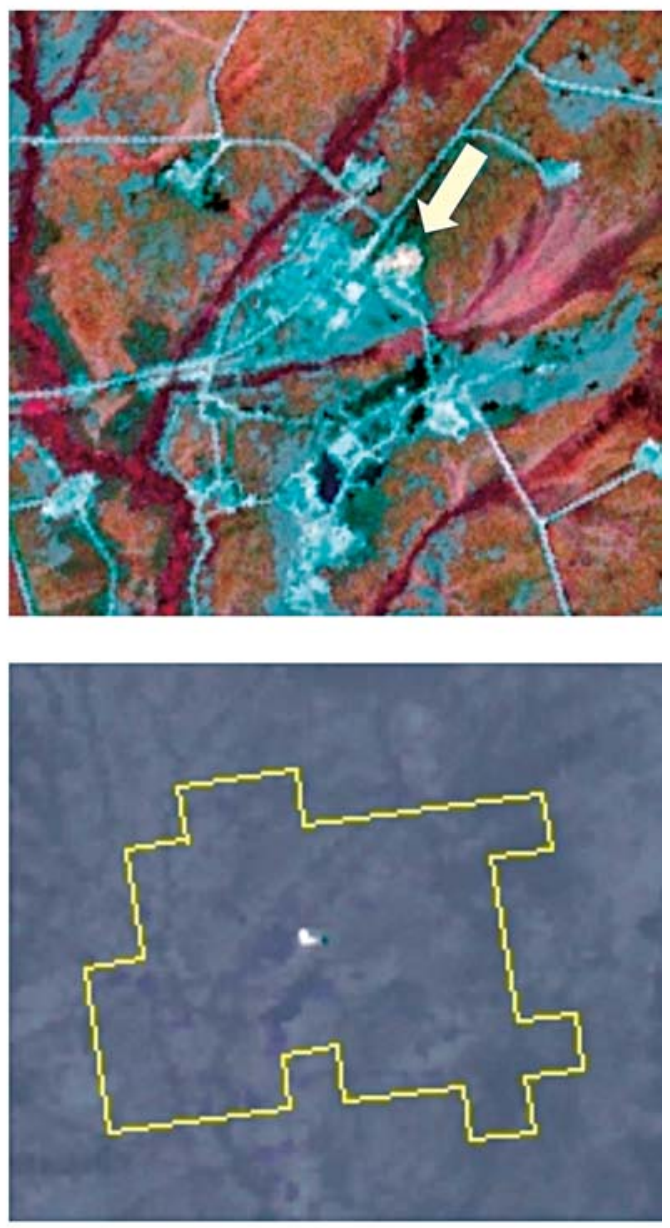

d

Figure 4. The Verkhne-Kolikyeganskoye gas extraction facility as imaged by ASTER on 22 Aug 2001. (a) False color infrared image: near-infrared (ASTER band 3 ) coded as red, red (band 2) coded as green, and green (band 1) coded as blue on the image. (b) Enlarged subset of (a) showing the industrial site. (c) The same area as in (a) is shown in ASTER shortwave infrared bands: band 9 coded as red, band 4 coded as green, and band 7 coded as blue. (d) The same area as (a) is shown as ASTER thermal infrared image: band 10 coded as red, band 12 coded as green, and band 14 coded as blue. The area flagged as a thermal anomaly on the MOD 14 data $(0.92-\mathrm{km}$ pixel size) is shown as the yellow polygon.

to feature Y (e.g., LCTAs). High negative correlation values mean the distance in space from any pixel to feature $X$ is larger or smaller than the distance from any pixel to feature $Y$. Values close to 0 indicate that there is no relationship between the distances of the pixels from the two features. 


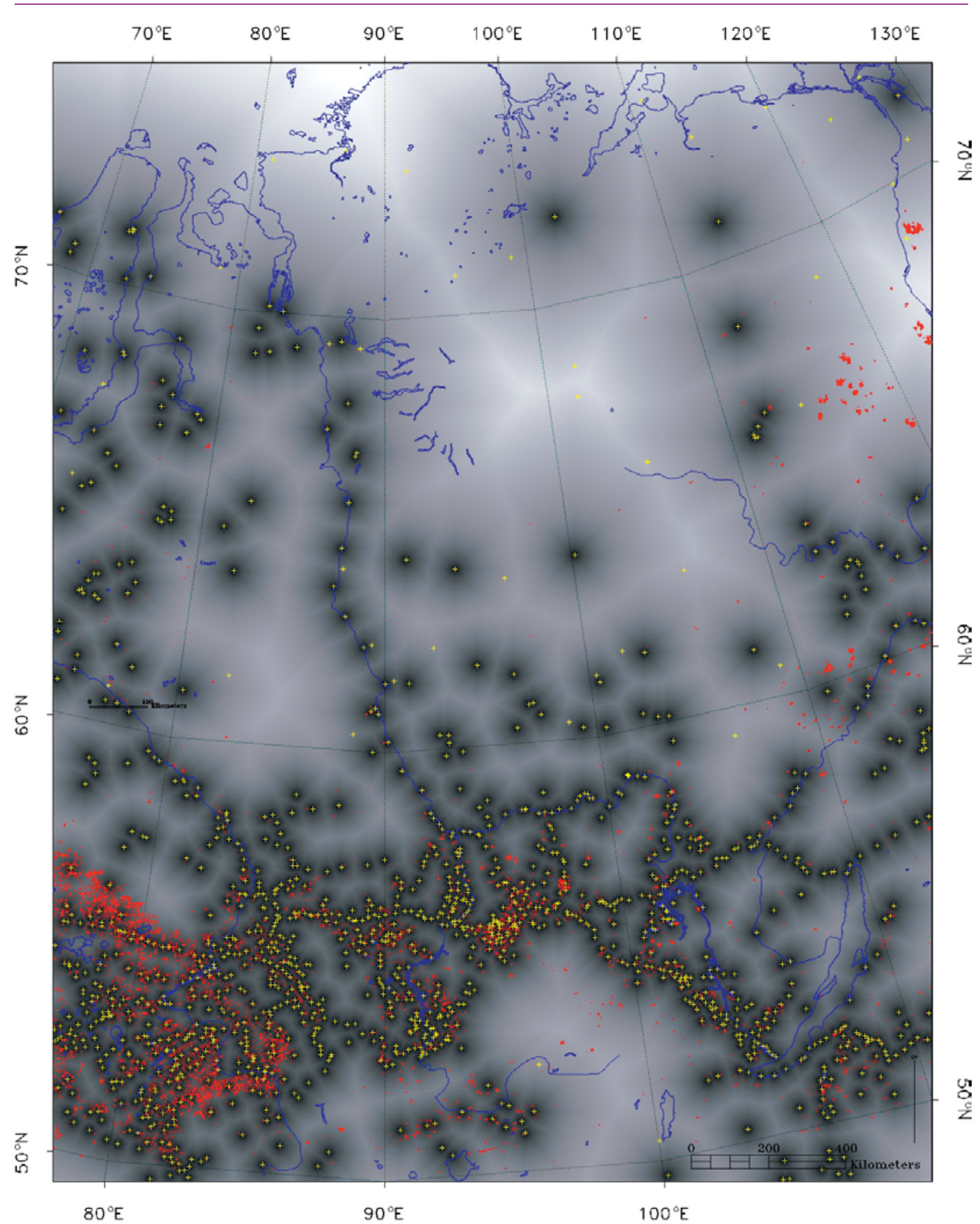

Figure 5. Continuous, unlimited buffer zones from human settlements (yellow) with 2001 LCTAs (red) overlaid.

The analysis of distance between fires and anthropogenic vector features (such as roads, settlements, etc.) also provided a way to isolate those thermal anomalies that are outside the likely influence of human activities. To examine this, the distance between each pixel labeled as an LCTA and an anthropogenic vector feature (such 
as roads) was assigned to that LCTA pixel. This was done for each anthropogenic feature separately. Then, the frequency of occurrence of these distance values was normalized by the total number of pixels of that distance from the feature.

\section{Results and discussion}

\subsection{Land-cover classification and thermal anomalies}

The land-use classification resulted in an overall accuracy of $87 \%$. The confusion matrix is shown in Table 2. The classification accuracy for different forest types (evergreen conifer, deciduous conifer, and deciduous broadleaf) were above 90\%; however, mixed forest (accuracy about $82 \%$ ) was confused with evergreen conifer forest. Grasslands $(80 \%)$ were confused with agriculture; wetlands $(84 \%)$ and the tundra class $(78 \%)$ were both confused with the "other vegetation" class (which includes shrubland and woodlands). The classification accuracy for the agriculture and barren land classes were both above $90 \%$. There was no water class because water bodies were masked out before the classification. This classification combined the strengths of the MOD12 and GLC classifications, while incorporating higher-resolution satellite data analysis (i.e., Landsat-7) and ground information.

Table 3 shows a summary of the occurrence of thermal anomalies by land-cover type for years 2001, 2002, and 2003. In 2003, 3 times more TAs were detected than in 2001. In the low and moderate fire years of 2001 and 2002, respectively, about one-third of all land burned belonged to forest, agricultural land, and other natural land. However, in the high fire year of 2003, one-half of all land area

Table 2. Confusion matrix of the maximum likelihood classification (MLC) landcover classification. Boldfaced values denote the percent of correctly classified pixels.

\begin{tabular}{|c|c|c|c|c|c|c|c|c|c|c|c|}
\hline \multirow[b]{2}{*}{ Class description } & \multirow[b]{2}{*}{ Class } & \multicolumn{10}{|c|}{ Testing sites } \\
\hline & & $1 \mathrm{ECF}$ & 2DCF & $3 \mathrm{DBF}$ & $35 \mathrm{MXF}$ & $36 \mathrm{OVG}$ & $5 \mathrm{GLN}$ & $6 \mathrm{WTL}$ & 14AGR & 13TDR & $12 \mathrm{BRN}$ \\
\hline $\begin{array}{l}\text { Evergreen } \\
\text { conifer forest }\end{array}$ & & 90.5 & 0.4 & 0.0 & 15.9 & 0.0 & 0.0 & 2.0 & 0.0 & 0.0 & 0.0 \\
\hline $\begin{array}{l}\text { Deciduous } \\
\text { conifer forest }\end{array}$ & $2 \mathrm{DCF}$ & 1.3 & 92.5 & 0.9 & 0.0 & 2.8 & 0.0 & 0.8 & 0.0 & 0.1 & 0.0 \\
\hline $\begin{array}{l}\text { Deciduous } \\
\text { broadleaf forest }\end{array}$ & $3 \mathrm{DBF}$ & 0.1 & 1.4 & 94.6 & 1.1 & 0.0 & 3.7 & 0.0 & 3.4 & 0.8 & 0.0 \\
\hline Mixed forest & $35 \mathrm{MXF}$ & 6.0 & 0.5 & 0.3 & 82.7 & 0.0 & 0.0 & 0.9 & 0.0 & 0.0 & 0.0 \\
\hline $\begin{array}{l}\text { Other vegetation } \\
\text { (shrubs, woodlands) }\end{array}$ & $36 \mathrm{OVG}$ & 0.0 & 1.5 & 0.0 & 0.0 & 86.4 & 0.0 & 7.9 & 0.0 & 13.4 & 0.0 \\
\hline Grasslands & $5 \mathrm{GLN}$ & 0.1 & 0.7 & 1.2 & 0.0 & 0.0 & 80.3 & 0.3 & 4.3 & 1.5 & 0.0 \\
\hline Wetlands and bogs & $6 \mathrm{WTL}$ & 1.9 & 1.3 & 0.2 & 0.4 & 5.2 & 0.0 & 84.6 & 0.0 & 0.5 & 0.0 \\
\hline Agriculture & 14AGR & 0.0 & 0.2 & 2.7 & 0.0 & 0.0 & 13.6 & 0.4 & 92.3 & 1.5 & 0.0 \\
\hline Tundra & 13TDR & 0.1 & 1.6 & 0.2 & 0.0 & 5.6 & 2.4 & 3.1 & 0.0 & 77.7 & 0.5 \\
\hline \multirow{4}{*}{$\begin{array}{l}\text { Barren or sparely } \\
\text { vegetated }\end{array}$} & 12BRN & 0.0 & 0.0 & 0.0 & 0.0 & 0.0 & 0.0 & 0.0 & 0.0 & 4.4 & 99.5 \\
\hline & Total & 100.0 & 100.0 & 100.0 & 100.0 & 100.0 & 100.0 & 100.0 & 100.0 & 100.0 & 100.0 \\
\hline & \multicolumn{3}{|c|}{ Overall accuracy } & $87.4 \%$ & & & & & & & \\
\hline & \multicolumn{3}{|c|}{ Kappa coefficient } & 0.857 & & & & & & & \\
\hline
\end{tabular}


Table 3. Number of $0.86-\mathrm{km}^{2}$ pixels, percentages, and area covered by MODIS thermal anomalies for each land-cover class for years 2001, 2002, and 2003. AGTA are thermal anomalies occurring on agricultural lands, other open TAs are thermal anomalies occurring on nonagricultural open lands such as steppe grasslands or tundra, and ITA are industrial thermal anomalies.

\begin{tabular}{lrcr}
\hline & \multicolumn{3}{c}{ No. of pixels } \\
\cline { 2 - 4 } & 2001 & 2002 & 2003 \\
\hline Forest TA & 11065 & 16626 & 5002 \\
AG TA & 11499 & 17536 & 20913 \\
Other open TA & 8679 & 12746 & 23357 \\
ITA & 150 & 143 & 147 \\
Total & 31393 & 47051 & 94419 \\
& & Percent of yearly total & \\
\cline { 2 - 4 } & 2001 & 2002 & 2003 \\
\hline Forest TA & $35.25 \%$ & $35.34 \%$ & $52.96 \%$ \\
AG TA & $36.63 \%$ & $37.27 \%$ & $22.15 \%$ \\
Other TA & $27.65 \%$ & $27.09 \%$ & $0.16 \%$ \\
ITA & $0.48 \%$ & $0.30 \%$ & $100.00 \%$ \\
Total & $100.00 \%$ & $100.00 \%$ & \\
& & & \\
& 2001 & Area $\left(\mathrm{km}{ }^{2}\right)$ & 42003 \\
\hline Forest TA & 2002 & 17933 \\
AG TA & 9501 & 14276 & 20055 \\
Other TA & 9873 & 15057 & 126 \\
ITA & 7452 & 10944 & 81071 \\
Total & 129 & 123 & \\
\hline
\end{tabular}

burned was forested. The amount of ITAs remained about the same throughout the $3 \mathrm{yr}$ at around 145 pixels affected, indicating that this ITA detection method is independent from year-to-year climate variations. Figure 6 shows the detected TA area for all $3 \mathrm{yr}$ by land-cover type.

\subsection{Relationship of thermal anomalies to the landscape}

The proximity of thermal anomalies to anthropogenic features such as roads, rail lines, settlements, and industrial areas may be a useful indicator of the likely origin of the thermal anomaly. Figures 7a, 7b, and 7c show the normalized LCTA values (the portion of burned land area divided by all land area in each bin) from roads in the study area. As seen in Figure 7a, in 2001, 1.8\% of the land area burned within five pixels (about $5 \mathrm{~km}$ ) from roads. The spikes that are seen at large distances from roads (e.g., $1800 \mathrm{~km}$ ) on the 2001 histogram are due to a few large fires occurring in a remote area. Since these remote areas are relatively rare (i.e., there is not a lot of land area this far away from roads) and a relatively large percent (1.65\%) of these remote areas burned, these large, remote fires show up as spikes on the 2001 plot. Table 4 summarizes the areas of all land at different distances from roads, railroads, and settlements. About 0.7 million $\mathrm{km}^{2}$ of land is at a distance of between 1500 and $2000 \mathrm{~km}$ from roads. This area represents about $13 \%$ of all land 


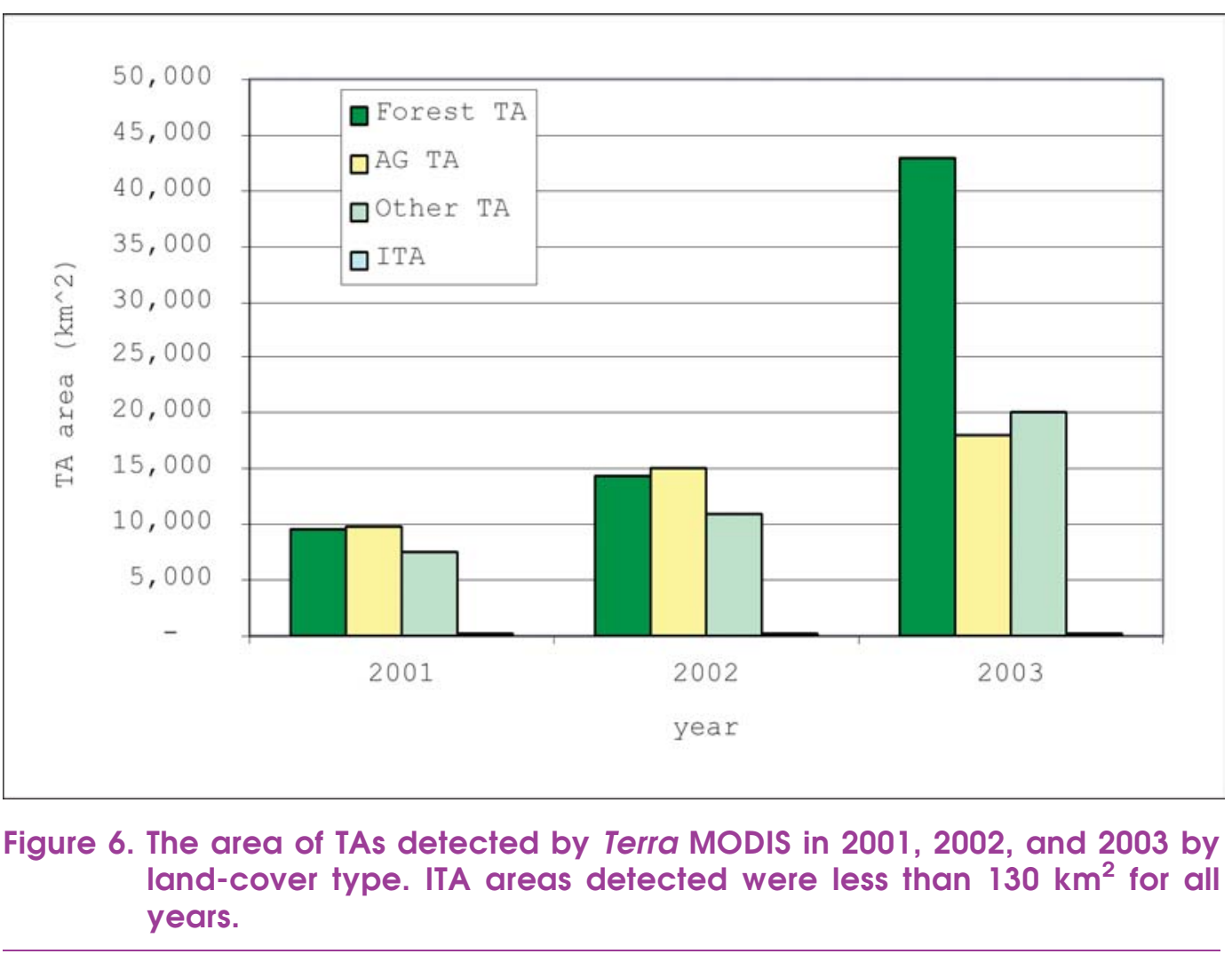

area. The cumulative percentage of LCTAs shows that most fires occur near roads and that the large, remote fires only contribute a few percent to the total number of pixels burned. These distance fires were not present in 2002 and 2003. This might have to do with weather conditions. The remote areas that burned in 2001 might have been drier than usual that year. In 2001, $84 \%$ of all LCTAs occurred within $300 \mathrm{~km}$ from roads. This number was $93 \%$ in 2002 and $97 \%$ in 2003. This is why only the first $300 \mathrm{~km}$ are shown in Figures $8 \mathrm{a}, 8 \mathrm{~b}$, and $8 \mathrm{c}$.

Figure $8 \mathrm{a}$ shows the normalized LCTA values from roads. In the high fire year of 2003 , about $4.5 \%$ of land burned within $5 \mathrm{~km}$ from roads. This value was only $1.8 \%$ for the low fire year of 2001. It can be observed that the normalized LCTA values show a small increase at around $20 \mathrm{~km}$ from roads and then decrease with distance from roads for all $3 \mathrm{yr}$. What is different between the curves for these years is the rate at which the normalized LCTA values drop off. In 2001, the normalized LCTA values level off after about $130 \mathrm{~km}$; however, in 2003, the values level off out at $300 \mathrm{~km}$. There are more local peaks in the 2003 curve than in the other years' data. At around $230 \mathrm{~km}$ from roads, the curves for the 2001 LCTAs and the 2002 LCTAs become similar.

A similar distribution is observed in Figure $8 b$, which shows the normalized LCTA values from railroads. Just as in the case of the relationship between the LCTAs and roads, the normalized LCTA values show a small increase at around $20 \mathrm{~km}$ from railroads, and then decrease with distance from railroads for all $3 \mathrm{yr}$. 
Earth Interactions • Volume 8 (2004) • Paper No. 18 • Page 18

a

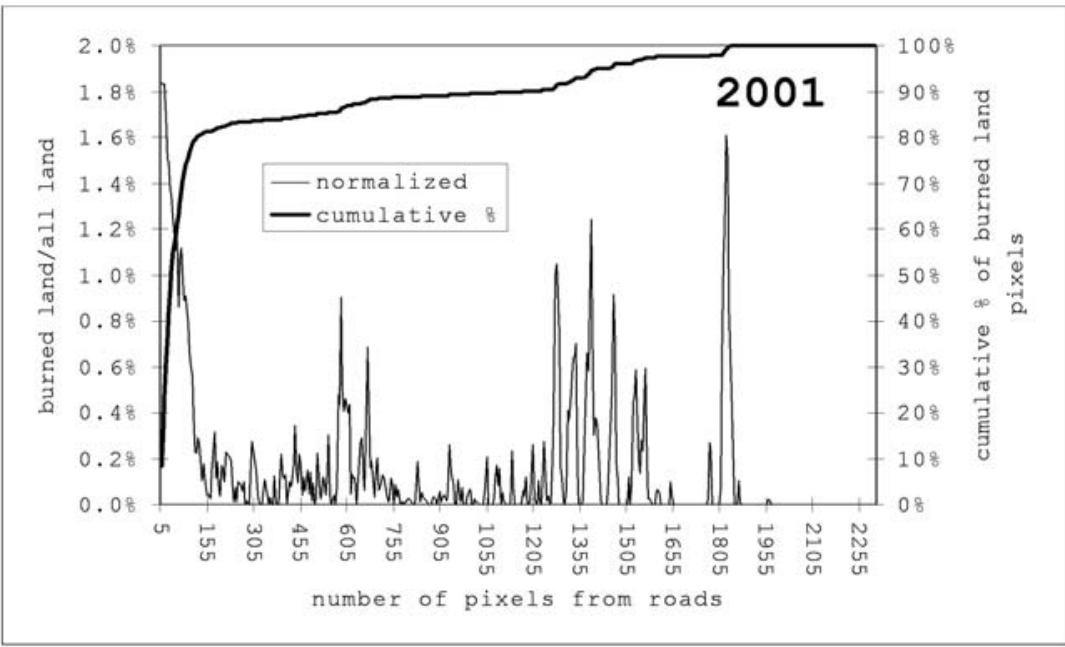

b

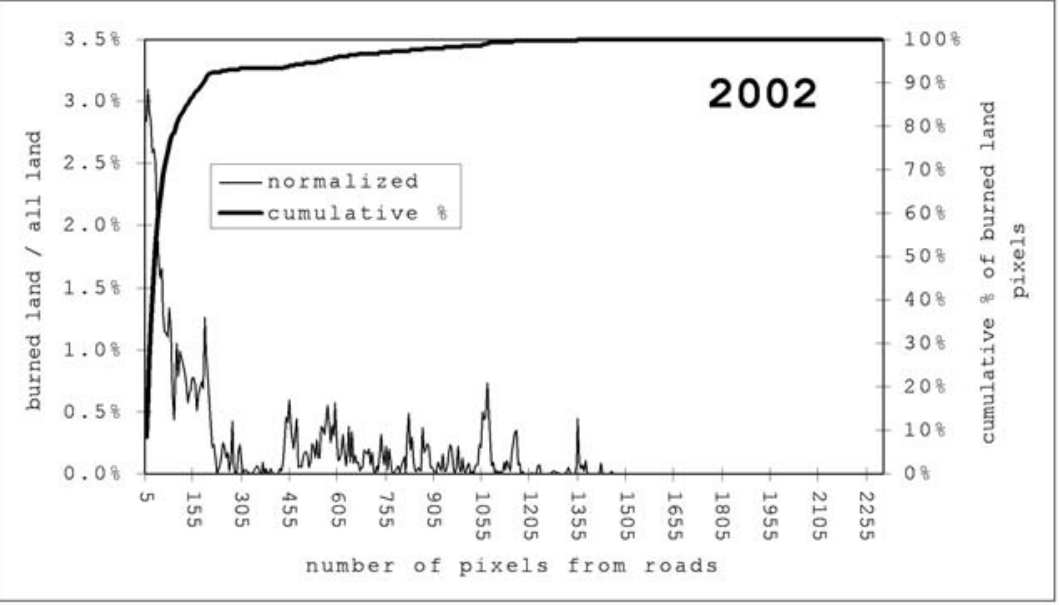

C

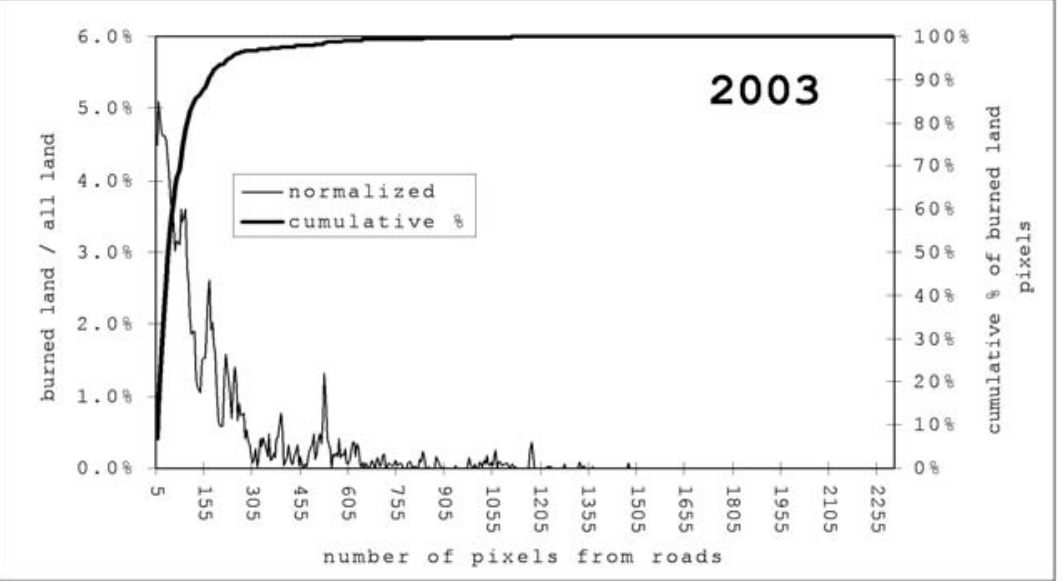

Figure 7. Histograms of the distances between LCTAs and roads in the study area: (a) 2001, (b) 2002, and (c) 2003. The spikes that are seen at far distances on the 2001 data were caused by a few large fires. 
Table 4. Summary of land area at different distances from major roads, railroads, and settlements.

\begin{tabular}{|c|c|c|c|c|c|c|}
\hline & \multicolumn{6}{|c|}{ Land area at distances $(\mathrm{km})$ from anthropogenic features } \\
\hline & $0-500$ & $501-1000$ & $1001-1500$ & $1501-2000$ & $>2000$ & Total \\
\hline $\begin{array}{l}\text { From major roads } \\
\qquad\left(1000 \mathrm{~km}^{2}\right)\end{array}$ & 2960 & 1043 & 1018 & 792 & 73 & 5887 \\
\hline From major roads $(\%)$ & $50.29 \%$ & $17.72 \%$ & $17.29 \%$ & $13.46 \%$ & $1.25 \%$ & $100.00 \%$ \\
\hline $\begin{array}{l}\text { From railroads } \\
\qquad\left(1000 \mathrm{~km}^{2}\right)\end{array}$ & 3729 & 1510 & 536 & 112 & - & 5887 \\
\hline From railroads $(\%)$ & $63.35 \%$ & $25.65 \%$ & $9.11 \%$ & $1.90 \%$ & $0.00 \%$ & $100.00 \%$ \\
\hline $\begin{array}{l}\text { From settlements } \\
\qquad\left(1000 \mathrm{~km}^{2}\right)\end{array}$ & 5822 & 64 & - & - & - & 5887 \\
\hline From settlements $(\%)$ & $98.91 \%$ & $1.09 \%$ & $0.00 \%$ & $0.00 \%$ & $0.00 \%$ & $100.00 \%$ \\
\hline
\end{tabular}

Again, the difference between the curves for these years is the rate at which the normalized LCTA values decrease. In 2001, the normalized LCTA values level off after about $200 \mathrm{~km}$ from railroads; however, in 2003, the values do not seem to level off out to $300 \mathrm{~km}$. There are again more local peaks in the 2003 curve than in the other years' data. At around $200 \mathrm{~km}$ from roads, the curves for the 2001 and the 2002 LCTAs become very similar, leveling off near zero.

Finally, Figure $8 \mathrm{c}$ shows the normalized LCTA values from settlements. The normalized LCTA values increase from 0 to $30 \mathrm{~km}$ from settlements, the values peak at around $30 \mathrm{~km}$ from settlements for every year, and then, just as in the case of the relationship between the LCTAs and roads and railroads, the values decrease with distance for all $3 \mathrm{yr}$. Again, the difference between the curves for these years is the rate at which the normalized LCTA values drop off. In 2001, the normalized LCTA values level off after about $150 \mathrm{~km}$; however, in 2003, the values decrease out to $180 \mathrm{~km}$ from settlements. There are more local peaks in the 2003 curve than in the other years' data. At around $230 \mathrm{~km}$ from roads, the curves for the 2001 and the 2002 LCTAs become very similar, leveling off near zero.

All this seems to indicate that regardless of the interannual variability in the number of fires, a similar relationship exists between LCTAs and the anthropogenic features. However, the interannual variability (likely related to climate variability) that drives the number of fires also seems to amplify the relationship of LCTAs and the anthropogenic features. In high fires years such as 2003, the relationship between proximity to roads and LCTAs seems more pronounced. This may be because winds may carry sparks for kilometers from burning trash or agricultural fields. In cool, humid years, the sparks are extinguished naturally. However, in warm, dry years there is more potential dry fuel, and the likelihood of ignition is higher farther from the anthropogenic activity. This way, the area of human influence might be dependent on the climatic conditions of a given year.

Not all LCTAs within 200 or $300 \mathrm{~km}$ from anthropogenic features are caused by people, and not all LCTAs outside of this threshold are natural. Lightning might strike anywhere. Instead, the results show that within this distance from anthropogenic features, the vegetation is more likely to catch on fire than in areas 
Earth Interactions • Volume 8 (2004) • Paper No. 18 • Page 20

a

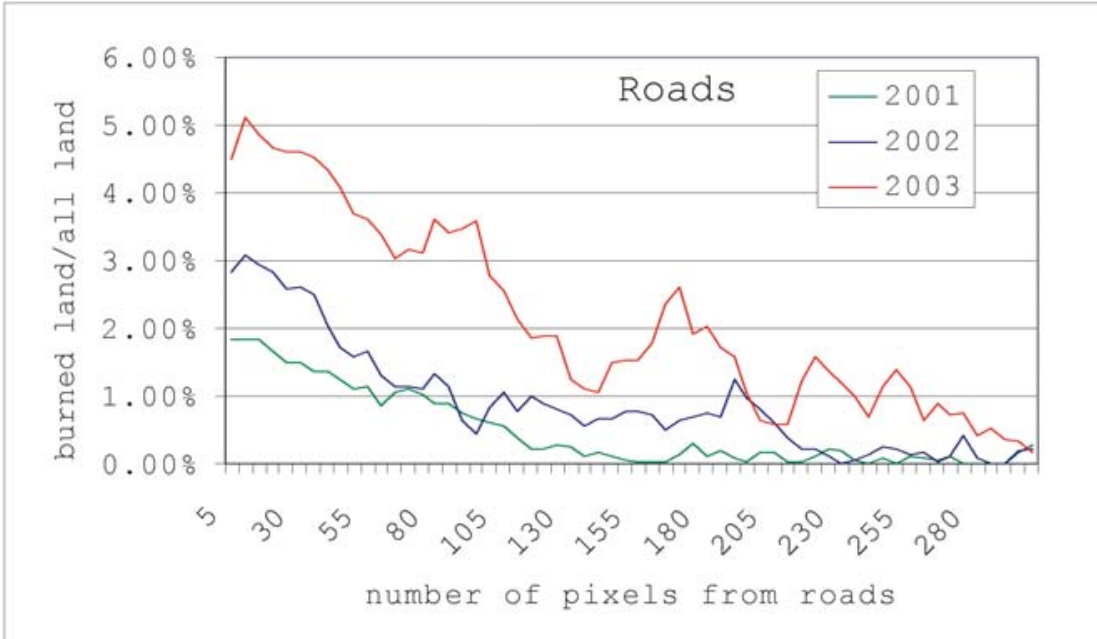

b

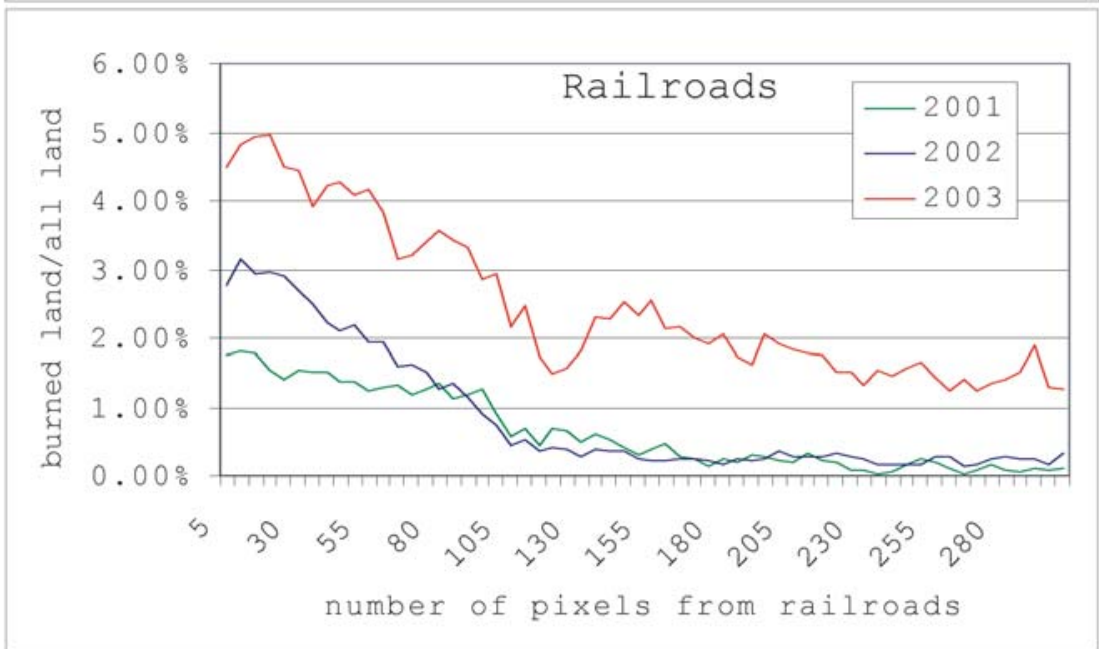

C

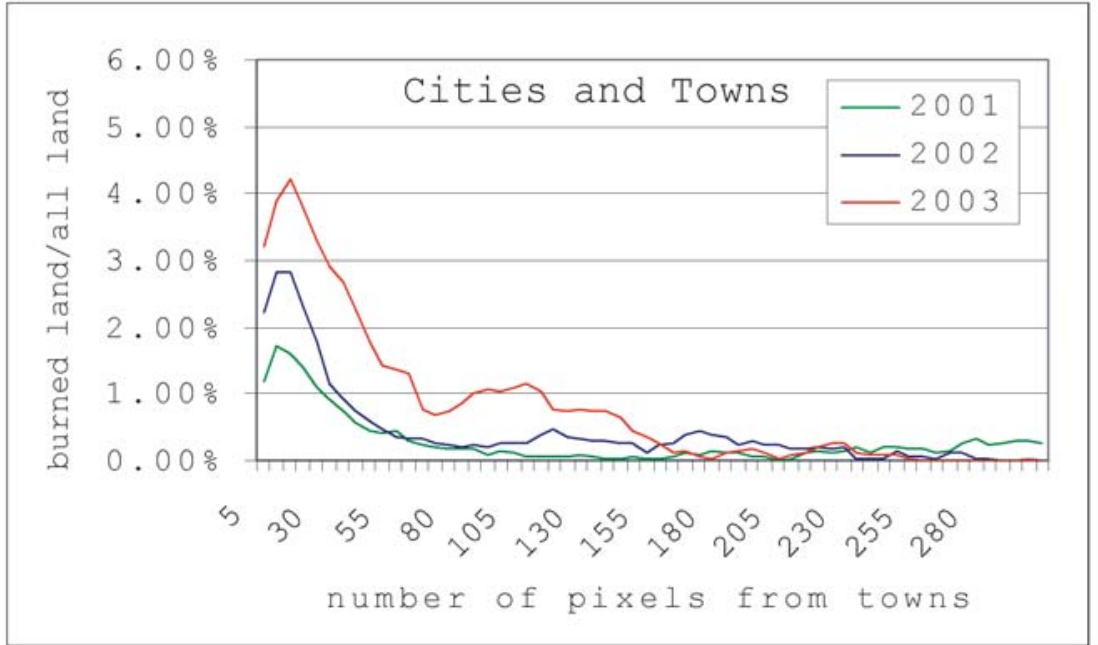

Figure 8. Histograms of the distance $(0.92-\mathrm{km}$ pixels) between anthropogenic features and LCTAs: (a) roads, (b) railroads, and (c) cities and towns. 
farther away. Part of this might have to do with a more indirect type of anthropogenic influence: roads and railroads create an edge effect in the forest. Edges are more likely to dry out and become prone to fire (Cochrane and Laurance 2002). Therefore, people might contribute to high TA numbers not only by accidentally setting fires but also by creating microclimatic conditions that promote the development of natural fires.

\subsection{Correlation analysis}

The correlation matrix shown in Table 5 lists the correlation values between the buffer zones of the features. The first nine rows contain information for either anthropogenic features (such as human settlements) or natural features that have human uses (rivers are used as a transportation network). The next three rows indicate land-cover classes such as forest, agricultural land, and other land. These are provided for comparison with the burned-land-cover areas. The next four rows are the 2001 thermal anomalies - of land cover and of industrial (ITA) origin. The LCTAs were labeled with the type of land cover upon which they occurred, based on the land-cover classification discussed earlier: forest TAs, agriculture TAs, and other open land TAs (grassland, tundra, barren and wetland, woodland and shrubland). The next four rows are the 2002 thermal anomalies, which are labeled similarly. Finally, the last four rows are the 2003 thermal anomalies. Since the anthropogenic features and land-cover classes did not change from one year to another, only the thermal anomaly fields are shown separately for 2001, 2002, and 2003 for the purposes of this study.

Some of the anthropogenic features have a strong, positive correlation with each other (such as roads and railroads, gas flares, and active oil and gas resources, etc.). Of the land-cover classes, the agricultural areas have a very strong correlation $\left(r^{2}=\right.$ 0.97 ) with roads and to a lesser extent with settlements, mining industry locations, and pipelines.

All three LCTA types in all 3 yr have a strong, positive correlation with some anthropogenic features, such as roads, human settlements, and mineral industry locations, and in the high fire year of 2003 these relationships seem to be in general stronger. The forest TAs and roads have very high positive correlation $\left(r^{2}{ }_{2001}=0.81, r_{2002}^{2}=0.90, r^{2}{ }_{2003}=0.88\right)$ in all years. The correlation is stronger between burned forests and roads $\left(r^{2} 2001=0.81, r_{2002}^{2}=0.90, r^{2}{ }_{2003}=0.88\right)$ than between any forest pixels and roads $\left(r^{2}=0.52\right)$ indicating that forest pixels near roads are more likely to burn than any forest pixel. The correlation between any agricultural land and any forest pixel is only 0.54 , whereas the correlation between burned agricultural land and burned forest is much higher $\left(r_{2001}^{2}=0.93, r_{2002}^{2}=\right.$ $0.87, r_{2003}^{2}=0.94$ ), indicating that burning of agricultural fields seems related to the burning of forest. The correlation between any agricultural land and any other natural land cover is only 0.18; however, the correlation between burned agricultural land and burned other natural land cover is much higher $\left(r_{2001}^{2}=\right.$ $\left.0.80, r_{2002}^{2}=0.81, r_{2003}^{2}=0.90\right)$, indicating that burning of agricultural fields seems also to be related to the burning of other natural vegetation.

Table 5 shows that anthropogenic feature and LCTA relationships tend to be stronger in a high fire year (2003) than in the low fire year (2001). Warming (and 
Table 5. Correlation matrix between (upper part of table) the buffer zones of transportation and cultural features, (middle part of table) the land-cover classes, and (lower part of table) thermal anomalies. Since each $r^{2}$ value was calculated based on over 7.6 million samples, all correlation coefficients are significantly different from zero at the $95 \%$ significance level. Boldfaced values as discussed in the text.

\begin{tabular}{|c|c|c|c|c|c|c|c|c|c|c|c|c|c|c|c|c|}
\hline Bands & 1 & 2 & 3 & 4 & 5 & 6 & 7 & 8 & 9 & 10 & 11 & 12 & 13 & 14 & 15 & 16 \\
\hline 1 Roads & 1.00 & & & & & & & & & & & & & & & \\
\hline 2 Railroads & 0.76 & 1.00 & & & & & & & & & & & & & & \\
\hline 3 Settlements & 0.68 & 0.53 & 1.00 & & & & & & & & & & & & & \\
\hline $\begin{array}{l}4 \text { Mining ind } \\
\text { locations }\end{array}$ & 0.78 & 0.67 & 0.50 & 1.00 & & & & & & & & & & & & \\
\hline $\begin{array}{l}5 \text { Mineral } \\
\text { reserves }\end{array}$ & 0.42 & 0.17 & 0.15 & 0.63 & 1.00 & & & & & & & & & & & \\
\hline $\begin{array}{l}6 \text { Active oil } \\
\text { and gas }\end{array}$ & -0.12 & 0.26 & 0.00 & -0.26 & -0.49 & 1.00 & & & & & & & & & & \\
\hline 7 Oil piplines & 0.91 & 0.86 & 0.70 & 0.65 & 0.14 & 0.15 & 1.00 & & & & & & & & & \\
\hline 8 All rivers & 0.30 & 0.09 & 0.35 & 0.26 & 0.36 & -0.14 & 0.19 & 1.00 & & & & & & & & \\
\hline 9 Gas flares & -0.23 & 0.12 & -0.09 & -0.34 & -0.46 & 0.97 & 0.01 & -0.05 & 1.00 & & & & & & & \\
\hline 10 All forest & 0.52 & 0.27 & 0.44 & 0.43 & 0.39 & -0.13 & 0.42 & 0.70 & -0.08 & 1.00 & & & & & & \\
\hline $\begin{array}{l}11 \text { All AG } \\
\text { land }\end{array}$ & 0.97 & 0.63 & 0.71 & 0.73 & 0.39 & -0.22 & 0.87 & 0.33 & -0.31 & 0.54 & 1.00 & & & & & \\
\hline $\begin{array}{l}12 \text { All other } \\
\text { land }\end{array}$ & 0.18 & 0.09 & 0.18 & 0.21 & 0.28 & 0.01 & 0.10 & 0.65 & 0.09 & 0.71 & 0.18 & 1.00 & & & & \\
\hline $\begin{array}{l}132001 \\
\text { forest TA }\end{array}$ & 0.81 & 0.37 & 0.69 & 0.59 & 0.35 & -0.29 & 0.71 & 0.41 & -0.34 & 0.58 & 0.91 & 0.24 & 1.00 & & & \\
\hline $\begin{array}{l}142001 \\
\text { AGTA }\end{array}$ & 0.95 & 0.60 & 0.72 & 0.72 & 0.40 & -0.25 & 0.85 & 0.31 & -0.35 & 0.53 & 0.99 & 0.17 & 0.93 & 1.00 & & \\
\hline $\begin{array}{l}152001 \\
\text { other TA }\end{array}$ & 0.67 & 0.33 & 0.66 & 0.56 & 0.36 & -0.25 & 0.58 & 0.47 & -0.27 & 0.58 & 0.77 & 0.34 & 0.89 & 0.80 & 1.00 & \\
\hline 162001 ITA & 0.56 & 0.76 & 0.47 & 0.45 & -0.02 & 0.47 & 0.70 & 0.19 & 0.40 & 0.37 & 0.52 & 0.25 & 0.37 & 0.49 & 0.34 & 1.00 \\
\hline $\begin{array}{l}132002 \\
\text { forest TA }\end{array}$ & 0.90 & 0.59 & 0.66 & 0.71 & 0.37 & -0.11 & 0.80 & 0.45 & -0.16 & 0.63 & 0.91 & 0.32 & 1.00 & & & \\
\hline 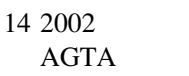 & 0.87 & 0.53 & 0.74 & 0.65 & 0.30 & -0.20 & 0.82 & 0.35 & -0.29 & 0.55 & 0.93 & 0.20 & 0.87 & 1.00 & & \\
\hline $\begin{array}{l}152002 \\
\text { other TA }\end{array}$ & 0.80 & 0.56 & 0.65 & 0.68 & 0.34 & -0.06 & 0.72 & 0.52 & -0.07 & 0.69 & 0.80 & 0.42 & 0.94 & 0.81 & 1.00 & \\
\hline 162002 ITA & 0.56 & 0.76 & 0.47 & 0.45 & -0.02 & 0.47 & 0.70 & 0.19 & 0.40 & 0.37 & 0.52 & 0.25 & 0.58 & 0.46 & 0.59 & 1.00 \\
\hline $\begin{array}{l}132003 \\
\text { forest TA }\end{array}$ & 0.88 & 0.55 & 0.71 & 0.71 & 0.37 & -0.14 & 0.80 & 0.42 & -0.20 & 0.62 & 0.93 & 0.28 & 1.00 & & & \\
\hline 142003 AGTA & 0.90 & 0.60 & 0.77 & 0.67 & 0.29 & -0.13 & 0.87 & 0.30 & -0.24 & 0.52 & 0.96 & 0.17 & 0.94 & 1.00 & & \\
\hline $\begin{array}{rl}15 & 2003 \\
& \text { other TA }\end{array}$ & 0.83 & 0.57 & 0.75 & 0.68 & 0.34 & -0.10 & 0.78 & 0.47 & -0.14 & 0.68 & 0.87 & 0.36 & 0.95 & 0.90 & 1.00 & \\
\hline 162003 ITA & 0.56 & 0.76 & 0.47 & 0.45 & -0.02 & 0.47 & 0.70 & 0.19 & 0.40 & 0.37 & 0.52 & 0.25 & 0.55 & 0.55 & 0.58 & 1.00 \\
\hline
\end{tabular}

drying) of the boreal region could positively enhance the effect people are having on the fire regime in this area. In turn, the building of roads creates more edges in the boreal forest, which could lead to further drying and an increase in the number of high fire years. A similar effect was reported by Cochrane and Laurance (Cochrane and Laurance 2002) in the tropical forest. Additionally, if lightning (the primary natural cause of fire) hits in a dry fragment, it will more likely result in a forest fire than if lightning struck a larger, more humid forest stand. 


\section{Conclusions}

Fire is an important disturbance mechanism in central Siberia. In the relatively low fire year of 2001, a thermal anomaly was detected by MODIS in approximately $0.45 \%$ of the landscape. This value was about $1.37 \%$ for the high fire year of 2003. By far, most fires were found in the southern portion of the study area with latitude less than $60^{\circ} \mathrm{N}$. However, several large fires were identified in the northeastern part in 2001. Transportation networks appear to play a role in the location and frequency of fires. Forest thermal anomalies show a stronger positive spatial correlation with roads $\left(r^{2}{ }_{2001}=0.81, r_{2002}^{2}=0.90, r_{2003}^{2}=0.88\right)$ than any forest pixel $\left(r^{2}=0.52\right)$ in all $3 \mathrm{yr}$, indicating that forests near roads are more likely to burn than any forest in the study area. This is also true for railroads, settlements, and mining industry locations. Forest thermal anomalies show a stronger positive spatial correlation with agricultural thermal anomalies $\left(r_{2001}^{2}=0.93, r_{2002}^{2}=0.87, r_{2003}^{2}=0.94\right)$ than any forest pixel $\left(r^{2}=\right.$ 0.53 ), indicating that forests near burning croplands are more likely to burn than any forest in the study area. These results suggest a strong link of human activity to land-cover fires as identified by the MODIS thermal anomaly data. These results also indicate that anthropogenic feature and LCTA relationships tend to be stronger in a high fire year (2003) than in a low fire year (2001).

In this study only Terra MODIS thermal anomaly data were examined. In our future studies we will also include Aqua MODIS data. The Terra MODIS MOD14 product detects not only burning land cover but also thermal anomalies that have industrial origin. In our continuing work, we will attempt to differentiate humancaused fires from natural fires and examine their impact on the carbon balance. The high correlations found in this study between land-cover fires and human activity does not confirm causation. Whether or not and how human presence and activity causes more land-cover fires to occur in central Siberia is a different question, and answering it would require more in-depth understanding of cultural practices in the area.

Acknowledgments. This work was funded by NASA's Office for Earth Sciences. Thanks to Marc Imhoff for access to DMSP stable lights data. We also thank the anonymous reviewers for their thoughtful suggestions.

\section{References}

Bartelev, S. A., A. S. Belward, D. V. Erchov, and A. S. Isaev, 2003: A new Spot-4 vegetation derived land cover map of northern Eurasia. Int. J. Remote Sens., 24, 1977-1982.

Brinkhoff, T., cited 2003: City population. [Available online at http://www.citypopulation.de.]

Cardille, J. A., S. J. Ventura, and M. G. Turner, 2001: Environmental and social factors influencing wildfires in the Upper Midwest, United States. Ecol. Appl., 11 (1), 111-127.

Causey, J., and J. Douglas, 1998: Minerals availability system (MAS/MILS database). U.S. Geological Survey, Denver, CO. [More information available online at http:// minerals.usgs.gov/sddp/doc/faq/mineralavailabilitysystem.faq.html.]

CIA, cited 1994: Transportation map. Central Intelligence Agency. [Available online at http:// www.odci.gov/cia/publications/index.html.]

Chapin, F. S., III, T. S. Rupp, A. M. Starfield, L. DeWilde, E. S. Zavaleta, N. Fresco, J. 
Henkelman, and A. D. McGuire, 2003: Planning for resilience: Modeling change in human-fire interactions in the Alaskan boreal forest. Front. Ecol. Environ., 1, 255-261.

Clark, W. A. V., and P. L. Hosking, 1986: Statistical Methods for Geographers. John Wiley and Sons, $518 \mathrm{pp}$.

Cochrane, M. A., and W. F. Laurance, 2002: Fire as a large-scale edge effect in Amazonian forests. J. Trop. Ecol., 18, 311-325.

Duncan, B. N., R. V. Martin, A. C. Staudt, R. Yevich, and J. A. Logan, 2003: Interannual and seasonal variability of biomass burning emissions constrained by satellite observations. $J$. Geophys. Res., 108, 4100, doi:10.1029/2002JD002378.

Elvidge, C. D., M. Imhoff, K. E. Baugh, V. R. Hobson, I. Nelson, J. Safran, J. B. Dietz, and B. T. Tuttle, 2001: Night-time lights of the world: 1994-1995. ISPRS J. Photogramm. Remote Sens., 56, 81-99.

Energy Information Administration, 1997: Oil and gas resources of the West Siberian Basin. DOE/EIA Rep. 0617, Office of Oil and Gas, U.S. Department of Energy, Washington DC, $156 \mathrm{pp}$.

ESRI, 2001: ARC 8.1. Environmental Systems Research Institute, Inc., Redlands, CA.

Friedl, M. A., and Coauthors, 2002: Global land cover mapping from MODIS: Algorithms and early results. Remote Sens. Environ., 83, 287-302.

Giglio, L., J. Descloitres, C. O. Justice, and Y. J. Kaufman, 2003: An enhanced contextual fire detection algorithm for MODIS. Remote Sens. Environ., 87, 273-282.

Guyette, R. P., R. M. Muzika, and D. C. Dey, 2002: Dynamics of an anthropogenic fire regime. Ecosystems, 5, 472-486.

Justice, C. O., and Coauthors, 2002: The MODIS fire products. Remote Sens. Environ., 83, 244-262.

Kajii, Y., and Coauthors, 2002: Boreal forest fires in Siberia in 1998: Estimation of area burned and emissions of pollutants by Advanced Very High Resolution Radiometer satellite data. J. Geophys. Res., 107, 4745, doi:10.1029/2001JD001078.

Kharuk, V. I., K. J. Ranson, T. A. Burenina, and E. V. Fedotova, 2003: Mapping of Siberian forest landscapes along the Yenisey transect with AVHRR. Int. J. Remote Sens., 24, 23 37.

Kasischke, E. S., and L. P. Bruhwiler, 2002: Emissions of carbon dioxide, carbon monoxide, and methane from boreal forest fires in 1998. J. Geophys. Res., 108, 8146, doi:10.1029/ 2001JD000461.

Kelha, V., and Coauthors, 2003: Combining AVHRR and ATSR satellite sensor data for operational boreal forest fire detection. Int. J. Remote Sens., 24, 1691-1708.

Kobak, K. I., I. Y. Turchinovich, N. Y. Kondrasheva, E. D. Schulze, W. Schulze, H. Koch, and N. N. Vygodskaya, 1996: Vulnerability and adaptation of the larch forest in eastern Siberia to climate change. Water Air Soil Pollut., 92, 119-127.

Li, Z., M. J. Apps, W. A. Kurz, and E. Banfield, 2003: Temporal changes of forest net primary production and net ecosystem production in west central Canada associated with natural and anthropogenic disturbances. Can. J. For. Res., 33, 2340-2351.

Mason, G. T., and R. E. Arndt, 1996: Mineral Resources Data System (MRDS). U.S. Geological Survey Digital Data Series DDS-20, U.S. Geological Survey, Reston, VA.

NOAA-NGDC, 1998: Stable Lights and Radiance Calibrated Lights of the World. National Oceanic and Atmospheric Administration-National Geophysical Data Center, Boulder, CO, CD-ROM.

Ranson, K. J., K. Kovacs, G. Sun, and V. I. Kharuk, 2003: Disturbance recognition in the boreal forest using radar and Landsat 7. Can. J. Remote Sens., 29, 271-285. 
Rodriguez-Trejo, D. A., and P. Z. Fule, 2003: Fire ecology of Mexican pines and a fire management proposal. Int. J. Wildland Fire, 12, 23-37.

RSI, 2000: The environment for visualizing images, version 3.4. Research Systems, Inc., Boulder, CO.

USGS, cited 2003: MODIS reprojection tool. [Available online at http://lpdaac2.usgs.gov/ landdaac/tools/modis/index.asp.]

Earth Interactions is published jointly by the American Meteorological Society, the American Geophysical Union, and the Association of American Geographers. Permission to use figures, tables, and brief excerpts from this journal in scientific and educational works it hereby granted provided that the source is acknowledged. Any use of material in this journal that is determined to be "fair use" under Section 107 or that satisfies the conditions specified in Section 108 of the U.S. Copyright Law (17 USC, as revised by P.IL. 94553) does not require the publishers' permission. For permission for any other form of copying, contact one of the copublishing societies. 